\section{Clinical Usefulness of Procalcitonin as a Marker of Sepsis: A Novel Predictor of Causative Pathogens?}

Key words: procalcitonin, sepsis

\section{(Intern Med 54: 1163, 2015)}

(DOI: 10.2169/internalmedicine.54.3749)

To the Editor We read the article by Nakajima et al. in a recent issue of Internal Medicine with great interest (1). In that article, the authors aimed to investigate the clinical utility of the procalcitonin (PCT) level as a marker of sepsis and subsequently concluded that the PCT level is a useful marker of the type of causative pathogen in patients with sepsis, whose measurement may facilitate the selection of appropriate empiric antibiotic treatment. Since the authors also categorized the patients according to the endotoxin levels, which increases the strength of the study, we would like to thank the researchers for their comprehensive contributions. However, we also wish to report a few concerns with this study.

In the reported study, it is remarkable that Staphylococcus aureus (S. aureus) was not included in the Gram-positive agent group when comparing the PCT levels between the patients with Gram-positive cocci and Gram-negative rods. The PCT level is affected by a variety of infectious agents and microbiological assessments are vital for evaluating the
PCT level. Previous studies have demonstrated that the PCT levels are higher in cases with Gram-negative results than in those with Gram-positive findings (2). Furthermore, a recent study showed that the PCT levels are higher in bacteremic patients with $S$. aureus infection than in those with coagulase-negative staphylococci (3). Therefore, it would have been more accurate to evaluate the causative microorganisms, including $S$. aureus, in the above study.

In conclusion, further studies are required to determine the relationships between the PCT level, causative pathogens and sepsis.

The authors state that they have no Conflict of Interest (COI).

Mustafa Hatipoglu and Ergenekon Karagoz

\section{References}

1. Nakajima A, Yazawa J, Sugiki D, et al. Clinical utility of procalcitonin as a marker of sepsis: a potential predictor of causative pathogens. Intern Med 53: 1497-1503, 2014.

2. Charles PE, Ladoire S, Aho S, et al. Serum procalcitonin elevation in critically ill patients at the onset of bacteremia caused by either Gram negative or Gram positive bacteria. BMC Infect Dis 8: 38 , 2008.

3. Shomali W, Hachem R, Chaftari AM, et al. Can procalcitonin differentiate Staphylococcus aureus from coagulase-negative staphylococci in clustered gram-positive bacteremia? Diagn Microbiol Infect Disease 76: 158-161, 2013.

Department of Infectious Diseases and Clinical Microbiology, GATA Haydarpasa Training Hospital, Turkey

Received for publication July 29, 2014; Accepted for publication August 24, 2014

Correspondence to Dr. Mustafa Hatipoglu, drtbpmh@gmail.com

(C) 2015 The Japanese Society of Internal Medicine Journal Website: http://www.naika.or.jp/imonline/index.html 